\title{
NAVIGÁCIÓ HÁLÓZATOKBAN BOLYAI JÁNOS GEOMETRIÁJA SEGÍTSÉGÉVEL
}

\author{
BÍRÓ JÓZSEF, GULYÁS ANDRÁS, RÉTVÁRI GÁBOR, KŐRÖSI ATTILA, \\ HESZBERGER ZALÁN, MAJDÁN ANDRÁS
}

\begin{abstract}
Ebben a tanulmányban röviden összefoglaljuk a Bolyai János Matematika Társulat 2016. évi Alkalmazott Matematikai Konferenciáján elhangzott előadás lényegét, amely a különböző komplex hálózatokban történő navigációról szólt. Jelen cikkben kiemelt figyelmet fordítunk az ún. skálafüggetlen hálózatokra, amelyekhez sok szempontból Bolyai János hiperbolikus geometriája jobban illeszkedik, mint az euklideszi tér. Röviden megmutatjuk, hogy a hiperbolikus geometria segítségével hogyan lehet meghatározni azokat a minimalisztikus (adott csomópontok esetén a lehető legkevesebb élt tartalmazó) hálózatokat, amelyek maximális mértékben navigálhatóak. Arról is értekezünk, hogy ezek a navigációs vázak strukturálisan hasonlóak számos valós hálózathoz és nagy mértékben benne is vannak azokban.
\end{abstract}

\section{Bevezetés}

A hálózattudomány paradigmája, hogy a bennünket körülvevő legkülönfélébb technológiai és természetben előforduló hálózatok (pl. internet, legijáratok hálózata, szavak szomszédossági hálózata, emberi agy strukturális hálózata) egységes keretrendszerben vizsgálhatók, felfedhetők a legkülönbözőbb topológiájú hálózatok közös vonásai, meghatározhatók a hálózati funkciók szempontjából lényeges tulajdonságaik.

A valóságban előforduló hálózatokban a navigáció alapvető fontosságú funkció. Technológiai hálózatokban ez általában azt jelenti, hogy a hálózat struktúrája alapján meg kell határozni azokat az útvonalakat, amelyek mentén a csomópontok között gazdaságosan és hatékonyan lehet az információt, utasokat, árut továbbítani. Közösségi/ismeretségi hálózatokban a navigáció kapcsán gondolhatunk pl. arra, hogy nem triviális feladat útvonalat találni ismeretségi kapcsolatokon keresztül egy számunkra ismeretlen emberhez. Biológiai hálózatokban is megfigyelhetők olyan jel-, energia- vagy információtovábbítási folyamatok, amelyek hálózatszintü navigációs koordinációra utalnak. Vannak olyan hálózatok is, amelyekről intuitíve érezzük, hogy valamilyen módon navigálhatók, de nagyon nehéz (vagy közvetlenül 
nem is lehetséges) tetten érni ezt a funkciót. Ilyen pl. a szavak szomszédossági hálózata, amely a fejünkben lévő mentális lexikon egyfajta lenyomatának is tekinthető. Amikor pl. beszélünk, agyunk a mentális lexikonban navigál, és ez rendkívül gyors, azonban a szavak hálózatán ezt a navigációt közvetlenül nem tudjuk megfigyelni.

A hálózattudományban az ún. mohó navigáció népszerü és sokat vizsgált funkció. A népszerüség oka valószínüleg az, hogy rendkívül egyszerű, a hálózati csomópontokról feltételezi, hogy nem ismerik a teljes topológiát, csak a velük közvetlen összeköttetésben lévőkről tudnak valamit. Stanley Milgram 1967-es kisvilág kísérletében demonstrálta, hogy emberek közötti ismeretségi hálózatban hatékonyan terjeszthető információ, amely a hálózat kisvilág tulajdonságának és a mohó navigációnak tulajdonítható. A mohó navigáció röviden úgy jellemezhető, hogy a hálózatban minden csomópont az információt annak a szomszádjának adja tovább, aki a célhoz a „legközelebbinek” tűnik. A modellezés szintjén ez implicite feltételezi egy rejtett metrikus tér jelenlétét, és az ezen történő távolságszámítás alkalmazását. Először Jon Kleinberg mutatta meg egy egyszerü, hosszú kapcsolatokat is tartalmazó euklideszi rácsmodellen, hogy a csomópontok a koordináták alapján történő mohó navigáció segítségével hatékonyan találnak rövid útvonalakat más csomópontokhoz [4].

\section{Mohó navigáció hálózatokban}

A mohó navigáció kapcsán fontos gráfelméleti kérdés, hogy egy véges összekötött irányítatlan gráf beágyazható-e valamilyen metrikus térbe oly módon, hogy bármely két pontja között legyen mohó útvonal. A válasz megadása előtt definiáljuk a mohó beágyazhatóság fogalmát.

2.1. Definíció. Mohó beágyazás: Egy $G$ irányítatlan gráf mohó beágyazása egy metrikus $(X, d)$ térbe jelentse azt az $f: V(G) \rightarrow X$ leképezést, amely rendelkezik a következő tulajdonsággal: minden különböző $s, t \in V(G)$ csúcspárhoz létezik egy $s$-sel szomszédos $u$ csúcs, amelyre $d(f(u), f(t))<d(f(s), f(t))$.

Ez azt jelenti, hogy ha egy gráf mohón beágyazható, akkor bármely két forrás-cél csúcspár között létezik olyan útvonal, amelyen a forrásból indulva és végighaladva, minden lépésben közelebb kerülünk a célhoz. Számos eredmény született arra vonatkozóan, hogy adott tulajdonságú gráfokat milyen metrikus térbe lehet mohón beágyazni. Egy jelentős negatív eredmény, hogy minden véges dimenziós normalizált vektortérhez találhatók olyan gráfok, amelyek abba mohó módon nem ágyazhatóak be. Speciális esetként ez pl. azt jelenti, hogy számos gráf az euklideszi síkba nem ágyazható be.

A fentiek fényében talán meglepőnek tűnhet a következő tétel:

2.1. TÉTEL. ([5]) Minden összekötött véges gráf mohón beágyazható a hiperbolikus síkba. 
Ez úgy interpretálható, hogy minden gráfhoz találhatók kétdimenziós hiperbolikus koordináták, amelyekkel a csomópontokat felcímkézve a gráfban a mohó útvonalválasztás megvalósítható. E nagyon általános eredmény hátrányaként mindenképpen meg kell említeni, hogy a tétel nem mond semmit az útvonalak hosszáról (két csomópont közötti mohó útvonal hány lépést tartalmaz), a csomópontok és az élek útvonalterheléséről (hány mohó útvonal halad rajtuk keresztül). Egy adott hálózatban a kialakítandó útvonalválasztás szempontjából ezek fontos műszaki jellemzők.

A fenti eredmények és az a tény, hogy a valóságban előforduló hálózatok nem akármilyenek, motiválták a következő (a mohó beágyazás szempontjából duálisnak tekinthető) problémakör felvetését. Tekintsük a hiperbolikus síkon a lehető legegyszerübb és legkevesebb paramétert használó hálózatgeneráló módszereket és az általuk előállított hálózatokat. Ezek a hálózatok vajon rendelkeznek-e a mohó navigálahtóság tulajdonságával. Milyen egyéb tulajdonságokkal rendelkeznek, hasonlítanak-e pl. a valóságban előforduló hálózatokhoz?

Egy ilyen nagyon egyszerü hiperbolikus generatív modell a következő [6]: Egy $R$ sugarú hiperbolikus körlapon helyezzünk el egyenletesen véletlenszerüen $N$ pontot, majd minden pontot kössünk össze a nála $R$-nél nem távolabbi pontokkal. Az így kialakult hálózatokról megmutatható, hogy számos valós hálózathoz hasonlóan fokszámeloszlásuk skálafüggetlen, kisvilág tulajdonságúak és klaszterezettségük pedig magas. Az is kimutatható, hogy az így generált hálózatok szinte 100\%-os mértékben mohón navigálhatóak (azaz bármely két csomópont között létezik mohó útvonal). Külön érdekes megfigyelés, hogy a mohó útvonalak rövidek és a hiperbolikus síkon közel vannak a geodetikus vonalakhoz. Ezek az eredmények számos további, a hiperbolikus geometria és a komplex hálózatok mélyebb megértését célzó kutatást inspiráltak. Talán az egyik legjelentősebb müszaki kutatási irányvonal annak vizsgálata, hogy az internet AS (autonomous System) szintü útvonalválasztó rendszerének teljes cseréje milyen feltételekkel és hatékonysággal lenne lehetséges [2]. Erre vonatkozóan kísérleti rendszer építése is folyamatban $\operatorname{van}[9]$.

\section{Mohó navigációs vázhálózatok}

Ebben a fejezetben bemutatjuk a hálózatok mohó navigációja terén elért saját eredményeinket. A korábbi fejezetben ismertetett generatív modell alapján úgy tünik, hogy a hasonló tulajdonságú valós hálózatok beágyazhatók a hiperbolikus síkba oly módon, mintha egy bizonyos paraméterü generatív hiperbolikus véletlen modell megvalósulásai lennének. Az irodalomból ismertek ilyen beágyazási algoritmusok, ezek leírásától most eltekintünk, csak annyit jegyzünk meg, hogy a beágyazások alapja lehet pl. a Markov-lánc Monte-Carlo-módszer [7]. A beágyazás eredményei a valós hálózat csomópontjaihoz rendelt kétdimenziós hiperbolikus koordináták. 
Mind a beágyazott hálózatok, mind pedig a generatív modellek esetén felvethető a következő kérdés: Csupán a csomópontok koordinátái alapján (egy pillanatra elfelejtve a csomópontok közötti éleket) meghatározható-e az a minimális számú élt tartalmazó hálózat, amely 100\%-os mértékben mohó navigálható. Egy ilyen maximálisan navigálható minimalisztikus vázhálózat létezése fontos szerepet kaphat a navigálható hálózatokban, amelyről egy kicsit később részletesebben is értekezünk. A következőkben bemutatunk egy nagyon egyszerü, bármely metrikus térben müködő hálózatformáló navigációs játékot, amelynek egy Nash egyensúlya a hiperbolikus sík esetén éppen a fent keresett navigációs vázhálózat.

\subsection{Definíció. Hálózatformáló navigációs játék:}

Stratégiák. A stratégiák tere egy $u \in \mathcal{P}$ játékos számára, amely szerint más játékosokhoz éleket húz a hálózatban, legyen $S_{u}=2^{\mathcal{P} \backslash\{u\}}$. Legyen $s$ egy vektor ebben a térben: $s=\left(s_{0}, s_{1} \ldots s_{N-1}\right) \in\left(S_{0}, S_{1} \ldots S_{N-1}\right)$, és $G(s)$ legyen az a gráf, amelyet $s$ generál, azaz $G(s)=\bigcup_{i=0}^{N-1}\left(i \times s_{i}\right)$.

Kiadás. A játékosok célja minimalizálni a kiadásaikat, azaz

$$
c_{u}=\sum_{\forall u \neq v} d_{G(s)}(u, v)+\left|s_{u}\right|, \quad u, v \in \mathcal{P},
$$

ahol

$$
d_{G(s)}(u, v)=\left\{\begin{array}{cc}
0, & h a \exists u \rightarrow v \text { mohó útvonal } G(s) \text {-ben, } \\
\infty & \text { egyébként. }
\end{array}\right.
$$

A fenti hálózatformáló navigációs játék Nash-egyensúlyairól megmutatható, hogy egyben szociális optimumot is biztosítanak, így meghatározásuk visszavezethető egy minimális halmazlefedési problémára [3]. Mivel több Nash-egyensúly is van, vizsgálatainkban mindig azt az egyensúlyi hálózatot határoztuk meg, amely az élek hosszának összegét is minimalizálja. Ez teljesen összhangban van az ún. éllokalitás elvvel [8] [4] [1], amely sokszor a valós hálózatokban megfigyelhető magas klaszterezettség egyik kiváltó oka lehet.

A hiperbolikus sík esetén a fenti játék Nash-egyensúlyi hálózatáról számos érdekes és fontos tulajdonságot bizonyítottunk analitikusan, amelyeket nagy számú numerikus vizsgálat eredményei is alátámasztottak [3]. Megmutattuk, hogy minden Nash-egyensúlyi hálózat tartalmaz egy bizonyos hálózati topológiát, és benne van egy másik bizonyos hálózati topológiában. Ennek fontos következménye pl. az, hogy a Nash-egyensúlyi hálózat átlagos fokszáma 1 és 4 között van, a numerikus vizsgálatok alapján az átlagos fokszám 2,29. Bebizonyítottuk, hogy az egyensúlyi hálózat fokszámeloszlása jó közelítéssel hatványfüggvény, klaszterezettségi együtthatója pedig 0,447 körüli érték, azaz ezekben a strukturális jellemzőkben is hasonlítanak a valóságban megfigyelhető hálózatokhoz.

Megvizsgáltuk azt a kérdést is, hogy a hiperbolikus síkba beágyazott valós hálózatok esetén a csak a koordináták alapján generált Nash-egyensúlyi hálózat milyen mértékben van benne az eredeti valós hálózatban. A vizsgált hálózatok az USA 


\begin{tabular}{|c|c|c|c|c|}
\hline & Internet & Metabolikus & Szavak & Repterek \\
\hline Csomópontok & 4919 & 602 & 4065 & 283 \\
\hline Élek & 28361 & 2498 & 38631 & 1973 \\
\hline Nash egyensúlyi vázháló élek & 5490 & 743 & 4634 & 328 \\
\hline Tartalmazás & $83 \%$ & $87 \%$ & $71,5 \%$ & $84 \%$ \\
\hline Navigációs sikerességi arány & $87 \%$ & $85 \%$ & $81 \%$ & $89 \%$ \\
\hline
\end{tabular}

1. táblázat

légiforgalmi hálózata, az internet AS szintü topológiája, egy metabolikus hálózat és a szavak egy bizonyos szomszédossági hálózata voltak. Az 1. táblázat mutatja a csomópontok és élek száma mellett a tartalmazást, amely azt jelenti, hogy a Nashegyensúlyi hálózat élei közül hány százalék van benne az eredeti hálózatban is. A navigáció sikerességi aránya azt jelenti, hogy az eredeti hálózatban a beágyazás után a csomópontpárok hány százaléka között létezik mohó útvonal. Megfigyelhető, hogy a Nash-egyensúlyi hálózatok nagy mértékben benne vannak a valós hálózatokban, amely összhangban van a magas navigációs sikerességi aránnyal is. Randomizált nullmodellek segítségével azt is igazoltuk, hogy a magas tartalmazási arány nem lehet a véletlen müve.

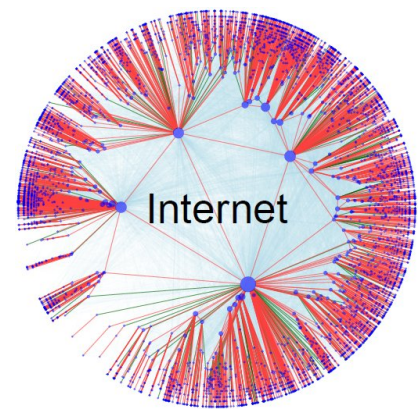

1. ábra. Az internet AS topológia élei (halványkék), a Nash-egyensúlyi hálózat élei (a pirosak részei az eredeti internet topológiának, a zöldek nem).

\section{Köszönetnyilvánítás}

A cikkben szereplő kutatások az OTKA FK_17 123957., KH_18 129589., K_17 124171. pályázatok támogatásával valósultak meg. Heszberger Zalánt az MTA Bolyai János Kutatási Ösztöndíj, valamint az UNKP-19-4 Új Nemzeti Kiválóság Program keretében az Emberi Erőforrások Minisztériuma támogatta. A támogatásokért a szerzők köszönetüket fejezik ki. 


\section{Hivatkozások}

[1] Boguna, M., Krioukov, D., and Claffy, K. C.: Navigability of complex networks, Nature Physics, Vol. 5 No. 1, pp. 74-80 (2009). DOI: 10.1038/nphys1130

[2] Boguná, M., Papadopoulos, F., and Krioukov, D.: Sustaining the internet with hyperbolic mapping, arXiv preprint arXiv:1009.0267. DOI: 10.1038/ncomms1063

[3] Gulyás, A., Bíró, J. J., Körösi, A., Rétvári, G., And Krioukov, D.: Navigable networks as Nash equilibria of navigation games, Nature communications, Vol. 6. DOI: $10.1038 /$ ncomms 8651

[4] Kleinberg, J. M.: Navigation in a small world, Nature, Vol. 406 No. 6798, pp. 845-845 (2000). DOI: $10.1038 / 35022643$

[5] KleInBerg, R.: Geographic routing using hyperbolic space, in: INFOCOM 200\%. 26th IEEE International Conference on Computer Communications. IEEE, pp. 1902-1909, IEEE (2007). DOI: 10.1109/INFCOM.2007.221

[6] Krioukov, D., Papadopoulos, F., Kitsak, M., Vahdat, A., and Boguná, M.: Hyperbolic geometry of complex networks, Physical Review E, Vol. 82 No. 3, (2010), 036106. DOI: 10.1103/PhysRevE.82.036106

[7] Papadopoulos, F., Kitsak, M., Serrano, M. Á., Boguná, M., and Krioukov, D.: Popularity versus similarity in growing networks, Nature, Vol. 489 No. 7417, pp. 537-540 (2012). DOI: $10.1038 /$ nature11459

[8] Watts, D., Dodds, P., And Newman, M.: Identity and search in social networks, Science, Vol. 296 No. 5571, p. 1302 (2002). DOI: 10.1126/science.1070120

[9] Zhang, L., Afanasyev, A., Burke, J., Jacobson, V., Crowley, P., Papadopoulos, C., Wang, L., Zhang, B., et al.: Named data networking, ACM SIGCOMM Computer Communication Review, Vol. 44 No. 3, pp. 66-73 (2014). DOI: 10.1145/2656877.2656887

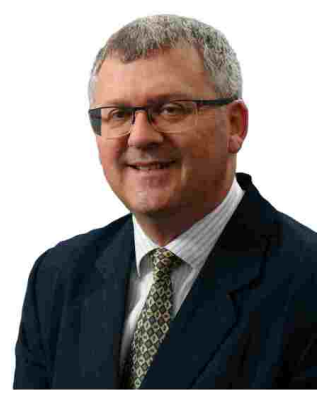

Bíró József 1968-ban született. 1993-ban végzett a BME Villamosmérnöki Karán okleveles villamosmérnökként, $\mathrm{PhD}$ fokozatát 1998-ban kapta meg. Doktori disszertációjának témája mesterséges neurális hálózatok távközlési alkalmazásai. Jelenleg a BME Villamosmérnöki és Informatikai Kar Távközlési és Médiainfomatikai Tanszék egyetemi tanára, valamint a karon müködő Villamosmérnöki Tudományok Doktori Iskola vezetője. Bíró József habilitációs doktori és MTA doktori címét 2009-ben kapta meg. Kétszer nyerte el az MTA Bolyai János Kutatási Ösztöndíját. Kutatási területe kommunikációs hálózatok és informatikai rendszerek matematikai modellezése, nagy hálózatok geometriája.

\section{BÍRÓ JÓZSEF}

Budapesti Müszaki és Gazdaságtudományi Egyetem

Távközlési és Médiainformatikai Tanszék

1117 Budapest, Magyar tudósok krt. 2.

biro@tmit.bme.hu 


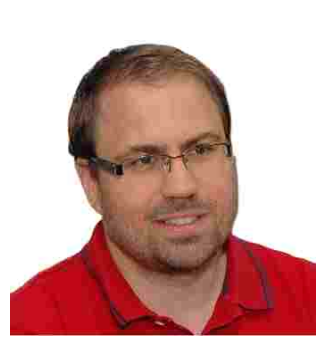

Dr. Gulyás András 2002-ben szerzett informatikus oklevelet a Budapesti Müszaki és Gazdaságtudományi Egyetem (BME) Villamosmérnöki és Informatikai Karán. PhD fokozatát 2008-ban kapta meg. Jelenleg tudományos fömunkatárs és kutatási témavezető a BME Villamosmérnöki és Informatikai Kar Távközlési és Médiainformatikai Tanszékén. Kutatási területe a hálózatkutatás és az útvonalkutatás.

\section{GULYÁS ANDRÁS}

Budapesti Műszaki és Gazdaságtudományi Egyetem

Távközlési és Médiainformatikai Tanszék

1117 Budapest, Magyar tudósok krt. 2.

gulyas@tmit.bme.hu

Rétvári Gábor arcképe és életrajza a szám egy másik cikkénél jelenik meg, mely cikknek szintén szerzője.

Budapesti Müszaki és Gazdaságtudományi Egyetem

Távközlési és Médiainformatikai Tanszék

1117 Budapest, Magyar tudósok krt. 2.

retvari@tmit.bme.hu

Kőrösi Attila arcképe és életrajza a szám egy másik cikkénél jelenik meg, mely cikknek szintén szerzője.

Budapesti Műszaki és Gazdaságtudományi Egyetem

Távközlési és Médiainformatikai Tanszék

1117 Budapest, Magyar tudósok krt. 2.

korosi@tmit.bme.hu

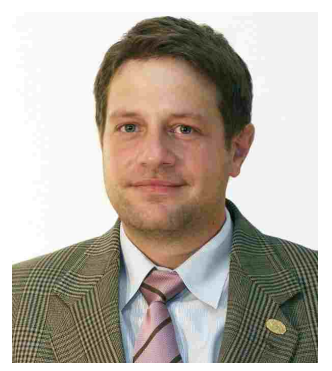

Heszberger Zalán 1997-ben végzett okleveles villamosmérnökként, ill. PhD oklevelét 2007-ben kapta meg a Budapesti Müszaki és Gazdaságtudományi Egyetemen. Doktori disszertációjának témája a kevés-paraméteres forgalombecslő eljárások fejlesztése és teljesítményelemzése. Jelenleg egyetemi docensként tevékenykedik a Távközlési és Médiainformatikai Tanszéken, ahol oktatási tevékenysége az internet hálózati kommunikációs technológiája és annak matematikai modellezése köré csoportosul. Tudományos kutatásaiban a jövő internet technológiák és protokollok hálózattudományi és információelméleti megközelítéseivel foglalkozik.

\section{HESZBERGER ZALÁN}

Budapesti Müszaki és Gazdaságtudományi Egyetem

Távközlési és Médiainformatikai Tanszék

1117 Budapest, Magyar tudósok krt. 2.

heszi@tmit.bme.hu 


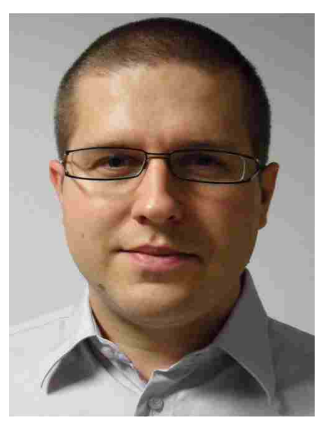

Majdán András a Budapesti Műszaki és Gazdaságtudományi Egyetemen szerzett mérnök informatikus diplomát, majd később PhD-abszolutóriumot. Főbb kutatási területei az adattömörítés, a teljesítményanalízis, memóriák elhasználódásának optimalizálása és a hálózattudomány. Az egyetemen a Távközlési és Médiainformatikai Tanszéken tanársegédként dolgozik. Főbb oktatott anyagai közé tartozik az IP alapú hangtovábbítás, a hálózati címfordítás és a virtuális magánhálózatok. Jelenleg a doktori disszertációját írja.

\title{
MAJDÁN ANDRÁS
}

Budapesti Müszaki és Gazdaságtudományi Egyetem

Távközlési és Médiainformatikai Tanszék

1117 Budapest, Magyar tudósok krt. 2.

majdan@tmit.bme.hu

\section{NAVIGATION IN NETWORKS BY THE BOLYAI-LOBACHEVSKY HYPERBOLIC GEOMETRY}

\author{
JózSef Bíró, András Gulyás, Gábor RÉtvári, Attila Kőrösi, \\ Zalán Heszberger, András Majdán
}

In this paper we briefly overview greedy navigation issues in networks. We argue that in case of scale-free and small-world networks with high clustering the Bolyai-Lobachevsky hyperbolic geometry is suitable for greedy geometric navigation. We also highlight that Nash equilibrium networks that have the smallest possible number of links required to maintain $100 \%$ navigability, form skeletons of real networks and share with them their basic structural properties.

Keywords: navigation, complex networks, Bolyai-Lobachevsky hyperbolic geometry. 